\author{
Alma Linkeviciute ${ }^{\text {a,b }}$, Giovanni Boniolo ${ }^{\text {a,b }}$, Leonora Chiavari ${ }^{\text {c }}$, Fedro A. Peccatori, \\ ${ }^{a}$ Dipartimento di Scienze della Salute, University of Milano, Via Adamello 16, 20139 \\ Milano, Italy \\ ${ }^{b}$ Department of Experimental Oncology, European Institute of Oncology (IEO), Via \\ Adamello 16, 20139 Milano, Italy \\ ${ }^{\mathrm{c}}$ Fertility and Procreation in Oncology Unit, Gynecologic Oncology Department, European \\ Institute of Oncology, Via Ripamonti 435, 20141 Milan, Italy
}

\title{
Fertility Preservation in Cancer Patients: The Global Framework
}

\begin{abstract}
Cancer treatment is the most frequent cause of reduced fertility in cancer patients, with up to $80 \%$ of survivors affected. None of the established or experimental fertility preservation methods can assure parenthood; instead it may provide a future opportunity to overcome treatment induced sterility. Previous research demonstrated that fertility counselling has clinical and psychological benefit. Therefore, such patient services are recommended by internationally recognized guidelines. Around $70-75 \%$ of young cancer survivors in retrospective studies are reported to desire parenthood but the numbers of patients who use fertility preservation services prior treatment are significantly lower. Moreover, despite existing guidelines healthcare professionals worldwide lack practical knowledge and have personal biases which prevent addressing fertility preservation issues adequately. Surveys of healthcare professionals report the following barriers: lack of time and knowledge about existing options, poor prognosis, and delay in treatment, patient's age, partnership status, existing children, sexual orientation and socioeconomic situation. Moreover, fertility preservation consultation is not limited to medical aspects. Patient's fears, expectations and priorities shaped by personal values have to be addressed in a light of medical necessities, realistic survival prognosis, socio-cultural environment and availability of resources. We call for a need of framework for patient centred fertility counselling with a proposal that such framework should include support in decision making which would help patients to understand medical aspects of their cancer, realistic fertility preservation options, identify their preferences based on personal values and goals. Optional support services could also include legal guidance, psychological and spiritual support and financial counselling.
\end{abstract}

\section{Keywords}


Fertility preservation, cancer patients, cryopreservation, counselling, decision support

\section{Introduction}

Cancer is predominantly associated with older age, but it also affects children, adolescents and young adults. Survival rates are known to be the highest for patients aged between 15 and 44 [1], with 5-years survival ranging from 60 to $82 \%$ according to age, tumour site and country of treatment $[1,2,3,4,5,6]$. Cancer therapies, nevertheless effective, often come with undesirable side effects, some of which are for a lifetime. Among these, infertility may affect up to $80 \%$ of cancer survivors as a result of treatments [7].

Cancer itself is rarely a direct cause of infertility $[8,9]$. Chemotherapy, radiotherapy or surgical removal of reproductive organs is the most frequent determinants of infertility in cancer survivors [10].

\section{Cancer treatment effects on fertility}

Male germ cells are sensitive to injury caused by cytotoxic drugs [11]. Leydig cells are resistant to chemotherapy [8], thus infertility rather than impaired sexual function altered by endocrine milieu is more frequently reported after oncological treatments. In females, ability to conceive can be affected by previous exposure to chemotherapy, radiotherapy or surgery. Adequate follicular reserve, a functioning hypothalamic-pituitary-ovarian axis and a normal uterus are all necessary for a normal pregnancy [8]. Many chemotherapeutic agents are gonadotoxic, but alkylating agents pose the highest risk of permanent infertility [12]. Moreover, oocytes are extremely sensitive to ionizing radiation, with direct correlation with dose and increasing patient's age [12]. Cranial radiation, affecting the hypothalamic-pituitary axis, may also impair fertility $[12,13]$.

Established and experimental methods can be used to preserve fertility. None of them assure parenthood after cancer, thus unrealistic expectations or false hopes should be given to the patients [14]. The most established and clinically approved methods for fertility preservation are sperm cryopreservation for men; embryo and oocytes cryopreservation and ovarian transposition for women [15].

\section{Fertility preservation options for male patients}

Sperm cryopreservation is the only established method for male fertility preservation [15]. Usually 3 semen samples are frozen, with at least 48-hours abstinence periods between each 
collection. However, if there is an urgent need to start cancer therapy, fewer samples can be cryopreserved [16]. As single intracytoplasmic sperm injection (ICSI) is now commonly used in assisted reproduction, thus allowing the successful use of samples with few spermatozoa $[16,17]$. It has been reported that $21 \%$ of Hodgkin lymphoma survivors who cryopreserved sperm prior their treatment used it [18] and a live birth using sperm frozen 21 years ago has been described [19]. In prepubertal boys, testicular tissue cryopreservation is the only possibility for fertility preservation. Spermatogonial diploid stem cells could possibly develop into mature cells after transplantation [16], but this method still remains experimental at the present time [20]. There is also a concern that with testicular tissue autotransplant the malignancy can be reseeded [21].

\section{Fertility preservation options for female patients}

Embryos cryopreservation is the most established and successful method for female fertility preservation. It requires delaying cancer treatment by 2-3 weeks and the availability of a partner. If a partner is not available or where embryo cryopreservation is not permitted by law, oocytes cryopreservation is a valid alternative [16]. Oocyte cryopreservation is not considered experimental since 2013, by the American Society of Clinical Oncology (ASCO) and the European Society of Medical Oncology (ESMO) [22,23]. More than 1000 births have been reported worldwide from cryopreserved oocytes [22,24]. Summary of different guidelines and their implications on fertility preservation practices are given in Table 1.

Both embryo and oocyte cryopreservation need an ovarian stimulation with gonadotropins and oocyte harvesting. In oestrogen dependent tumours, there is concern that ovarian stimulation may increase disease recurrence [16]. The concomitant administration of Letrozole reduces oestrogen peak and disease free survival was similar in women who had ovarian stimulation, compared with women who did not have it [25] but available data is based on a few trials and short follow up periods. Ovarian transposition (also called oophoropexy or ovarian suspension) is the surgical translocation of ovaries from the irradiation field in pelvic area. This method does not protect against chemotherapy or wholebody irradiation [16].

Ovarian suppression using gonadotropin-releasing hormone agonists for fertility preservation remain controversial. There is no sufficient evidence that it protects gonadal function from gonadotoxic agents [22]. 
Ovarian tissue cryopreservation is laparoscopic removal of ovarian cortical tissue which is cryopreserved and transplanted back at the time when conception is desired [16]. Ovarian grafts can be transplanted back to the pelvis or subcutaneous areas for oocyte maturation [26]. There has not been pregnancies achieved using frozen-thawed ovarian tissue taken from prepubertal girls [27], possibly for the high numbers of abnormal non-growing oocytes [28]. Same as in testicular tissue auto-transplantation, ovarian tissue auto-transplantation can bring back malignancy.

Twenty eight live pregnancies have been achieved with orthotopic ovarian tissue transplant from patients with haematological malignancies and breast cancer [29]. Currently about 100 centres worldwide perform ovarian tissue cryopreservation [13]. Whole ovary cryopreservation is experimental method and no live births have been achieved using this technique. It has been reported that 2 babies were born from whole ovary transplantation in monozygotic twin donor [30]. Therefore, some authors suggest that cryopreservation and retransplantation of whole ovary is promising and further research should be encouraged [31].

Moreover, there is a group of oncology patients known as 'previvors' and they deserve a special attention in cancer treatment and fertility preservation debate. These patients have cancer history running in their families and are at increased risk to develop cancer early in their lives. They have to think about prophylactic therapies even before being diagnosed with cancer. Such prevention strategies are suggested for women who are BRCA1 and BRCA2 mutation carriers and have high risk of developing breast or ovarian cancer [32]. Women of African ancestry under age of 45 have an elevated risk of breast cancer at young age compared to Caucasian women and their cancers are more aggressive that present as oestrogen receptor negative tumours [33]. It is suggested that these different groups of patients might have special needs that are unmet during fertility preservation counselling [34].

Table 1

Guidelines for fertility preservation in cancer patients

Releasing body; Scope Main statements regarding toxicity of cancer

Reference year therapy, fertility preservation (FP) and future procreation 
American

Society for

Medicine -

ASRM; 2013
Reproductive

All cancer Clinicians should inform patients about FP

patients

options and future reproduction before

gonadotoxic treatment begins.

Concerns about welfare of resulting offspring are not sufficient reasons to deny assistance in reproduction.

Parents may act to preserve fertility for minors (assent and likeliness to provide future benefit).

PGD to avoid offspring inheriting high risk of cancer is acceptable.

Patients should have access to mental health, genetic and financial counsellors.

All cancer

Discuss FP with all patients of reproductive patients age (with parents or guardians of children and adolescents).

Clinical

Oncology -
ASCO; 2013

Refer interested (and ambivalent) patients to fertility specialist.

Address FP before treatment starts.

Document FP discussion in medical records.

Answer basic questions about FP and its impact on cancer treatment.

Refer patients to psychosocial providers if patients experience distress.

Encourage patients to participate in registries and clinical studies.

National Adolescents Fertility preservation should be an integral

Comprehensive and Young

Cancer Network Adult (15-

- NCCN, USA; 
with all women before initiation of treatment.

Women diagnosed with cancer during pregnancy require individualised treatment by multidisciplinary team.

All patients should have access to ageappropriate supportive care and medical subspecialty services.

European $\quad$ Focuses on Male: sperm banking should be planned

Society of

Medical

Oncology -

ESMO

(endorsed by

Japanese

Society of

Medical

Oncology -

JSMO); 2013 pregnant before treatment initiation.

women

with cancer Female: Young women desiring future but has a fertility should be counselled on available section for fertility preservation options before starting post- anti-cancer treatment. pubertal patients

$$
\begin{array}{ll}
\begin{array}{l}
\text { Young } \\
\text { women } \\
\text { (under 40) }
\end{array} & \begin{array}{l}
\text { Fertility issues should always be discussed } \\
\text { before the start of any breast cancer therapy. }
\end{array} \\
& \begin{array}{l}
\text { Discussion should allow time for reflection } \\
\text { and involve partner, if present. }
\end{array}
\end{array}
$$

Early referral to reproductive endocrinologist is warranted.

\begin{tabular}{|c|c|c|}
\hline $\begin{array}{l}\text { European } \\
\text { Society of } \\
\text { Human } \\
\text { Reproduction } \\
\text { and Embryology } \\
\text { - ESHRE ; } \\
\text { publishes ethical } \\
\text { considerations }\end{array}$ & $\begin{array}{l}\text { Does not } \\
\text { have a } \\
\text { guideline } \\
\text { specifically } \\
\text { for } \\
\text { oncology } \\
\text { patients }\end{array}$ & $\begin{array}{l}\text { Provides guidelines relevant to fertility } \\
\text { preservation in oncology: cryopreservation, } \\
\text { PGD, posthumous reproduction, infertility } \\
\text { treatment, wellbeing of ART children, } \\
\text { distinction between established and } \\
\text { experimental treatment (concerning oocyte } \\
\text { cryopreservation) at http://www.eshre.eu . }\end{array}$ \\
\hline
\end{tabular}

Breast Cancer

Specialists -

EUSOMA;

2014 


\section{What do patients think about fertility preservation and what happens in the real world?}

Retrospective surveys of cancer patients' views suggest that the majority have a strong desire to be informed about fertility preservation and available options $[31,38,39,40]$. Moreover, concerns about infertility are not limited to patients who are young and childless or/and have a partner [41]. It has been reported that up to $70-75 \%$ of young cancer survivors would like to have a child $[39,42]$ with up to $29 \%$ of women refusing life saving treatment because of fear to become infertile [42], including a case reports where refused therapy lead to foetal and maternal death [43]. However, significantly lower numbers actually proceed with fertility preservation procedures (Table 2). Despite proven clinical and psychological benefit $[41,44]$ and recommendations that cancer patients should be routinely asked about their interest to preserve fertility before starting cancer treatment (Table 1), nearly half of patients are not given information about the impact of cancer treatment on their future fertility (Table 2).

Studies on patients' attitudes and fertility preservation choices are being conducted worldwide. In Table 2 we summarized studies from the USA, Canada, Sweden and Germany which report patient attitudes and the choices they subsequently made in order to preserve fertility. It is important to note that patient surveys vary in a sample size, methods how surveys were conducted and reported response rate is often less than half of eligible participants which could mean that only patients who were concerned about fertility chose to answer the questions. Moreover, the reported sample sizes are often too small for making valid generalizations relevant to all cancer patients. However, these studies revealed some important aspects in fertility preservation practices. First, majority of cancer patients regardless of final decision find fertility consultations important part of their treatment planning. Second, there are still high numbers of patients reported who have not received any kind of fertility preservation consultation. This tendency seems to be apparent among female patients $[39,45]$ and especially among racial minorities in the USA [34]. UK study of women with breast cancer who were childless concluded that although guidelines are available, many women were not given adequate information or offered treatments or interventions to preserve fertility [38]. This leads to the third point that women preserve fertility less often than men.

For instance, study from Germany reports that only $40 \%$ of cancer patients who wanted children in the future underwent fertility preservation [39]. Results from Swedish cancer survivors' survey reveal large gender disparities in received information about treatment 
impact on fertility, with $80 \%$ of male and $48 \%$ of women informed and while $54 \%$ of male patients banked frozen sperm, only $2 \%$ of women underwent fertility preservation [45]. There are only scarce data available from countries other than those in North America and Europe. But it is likely that fertility preservation for cancer patient issues might share a lot of similarities with countries already researched. For instance, in Saudi Arabia less than 20\% male patients are referred to fertility specialist [46], which suggests that even male patients do not always take the full advantage of fertility preservation options.

Another study has been published recently comparing attitudes towards fertility loss among young breast cancer patients. This study collected data from Western and Eastern Europe, South Africa, Middle East and South America concluding that $59 \%$ of patients wanted to have children in the future but cure was the first priority and only less than $10 \%$ would accept lower chances of survival to preserve fertility [47]. These numbers suggest that the importance of fertility could have been overestimated but some other studies show that having a child could have a positive effect on cancer survivors helping them to stay well, feel complete and look forward to the future [47]. However, even women with positive attitudes about having children after cancer have fears that possible pregnancy would increase chances for cancer recurrence or transmitting the cancer risk to the future child $[47,48]$. On the other hand patients who already have children might focus more on survival than fertility preservation $[40,42]$ and as a result might be less likely to be offered fertility preservation consultation $[46,49]$. Therefore, discussing cancer treatment implications on fertility and possible fertility preservation options as well as providing patients with decisional support would significantly help to improve cancer care and benefit the patients in any country.

Table 2

Cancer patients' attitudes towards fertility preservation (FP)

$\begin{array}{lllll}\begin{array}{l}\text { Country; } \\ \text { Publication } \\ \text { year }\end{array} & \begin{array}{l}\text { Participants; } \\ \text { Type of study }\end{array} & \begin{array}{l}\text { Attitudes, } \\ \text { expectations, } \\ \text { experiences } \\ \text { regarding FP (\%) }\end{array} & \begin{array}{l}\text { Number of patients } \\ \text { who used FP and } \\ \text { methods (\%) }\end{array} & \text { Reference } \\ & & & & \\ \begin{array}{l}\text { Texas, USA; } \\ 2012\end{array} & \begin{array}{l}33 \text { African } \\ \text { American breast }\end{array} & \begin{array}{l}45 \% \text { reported } \\ \text { retrospectively }\end{array} & 1 \text { patient froze } & \text { [34] }\end{array}$




$\begin{array}{lll}\begin{array}{l}\text { cancer survivors } \\ \text { under age of } 45 ; \\ \text { semi-structured } \\ \text { phone interviews }\end{array} & \begin{array}{l}\text { that they had } \\ \text { wanted a child at } \\ \text { the time of } \\ \text { diagnosis }\end{array} & \begin{array}{l}\text { embryos and oocytes } \\ 1 \text { patient froze oocytes }\end{array} \\ & \begin{array}{l}48 \% \text { did not } \\ \text { remember having } \\ \text { discussed FP }\end{array} & \begin{array}{l}\text { pregnant after cancer } \\ \text { treatment }\end{array} \\ & \begin{array}{l}\text { with a doctor } \\ 14 \% \text { of those }\end{array} & \begin{array}{l}\text { 1 sought IVF } \\ \text { treatment }\end{array} \\ & \begin{array}{l}\text { who had } \\ \text { chemotherapy } \\ \text { have been } \\ \text { offered FP }\end{array} & \text { after their cancer } \\ & & \end{array}$

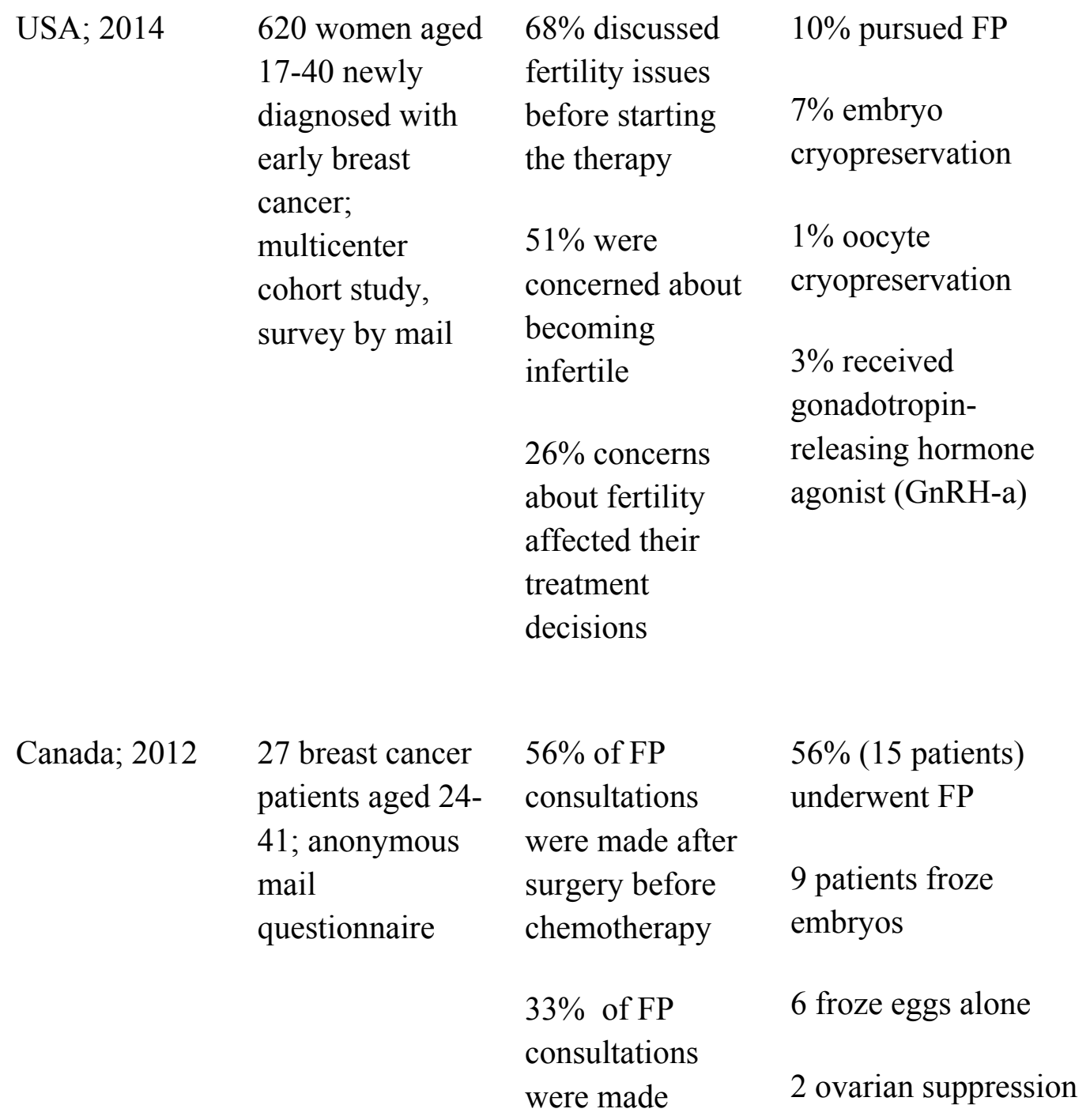


before surgery

$85 \%$

consultations

were made

within a week of

referral

Canada; 2012

41 female cancer

$97,6 \%$ regardless

$31,7 \%$ proceeded with

[41]

42, majority

of final decision

IVF for

breast cancer,

said that it was

cryopreservation (13

others ovarian

important to be

patients)

cancer,

seen by

reproductive

6 were planning to

lymphoma, brain

specialist

initiate pregnancy

cancer,

soon

Hodgkin's,

carcinoma,

leukaemia; mail

questionnaire

\begin{tabular}{|c|c|c|c|}
\hline Sweden; 2012 & $\begin{array}{l}484 \text { survivors } \\
\text { aged } 18-45 \text { at } \\
\text { diagnosis who } \\
\text { had lymphoma, } \\
\text { acute leukaemia, } \\
\text { testicular cancer, } \\
\text { ovarian cancer or } \\
\text { female breast } \\
\text { cancer treated } \\
\text { with } \\
\text { chemotherapy; } \\
\text { postal } \\
\text { questionnaire }\end{array}$ & $\begin{array}{l}80 \% \text { male } \\
\text { patients received } \\
\text { information } \\
\text { about treatment } \\
\text { impact on } \\
\text { fertility } \\
68 \% \text { male } \\
\text { patients received } \\
\text { information } \\
\text { about FP } \\
48 \% \text { female } \\
\text { patients received } \\
\text { information } \\
\text { about treatment } \\
\text { impact on } \\
\text { fertility }\end{array}$ & $\begin{array}{l}54 \% \text { male patients } \\
\text { banked sperm } \\
2 \% \text { female patients } \\
\text { underwent FP } \\
\text { including embryo and } \\
\text { oocyte } \\
\text { cryopreservation, } \\
\text { ovarian suppression, } \\
\text { radiation shielding of } \\
\text { gonads }\end{array}$ \\
\hline & & $\begin{array}{l}14 \% \text { female } \\
\text { patients received }\end{array}$ & \\
\hline
\end{tabular}


information on

FP

Germany; 2014

149 cancer

$74 \%$ had a desire

$56 \%$ male undergone

patients aged 18-

to have children

sperm

45; questionnaire

at the time of

cryopreservation

diagnosis

$31 \%$ female preserved

$60 \%$ discussed

fertility:

fertility with

oncologists

4 oocyte

cryopreservation

$20 \%$ discussed

fertility with

5 ovarian tissue

specialist

cryopreservation

13 took medication

\section{Healthcare professionals' attitudes towards fertility consultation in oncology patients}

It is suggested that individual plans for fertility preservation must take into account both patient's priorities and medical necessities [15], especially when healthcare systems are run on limited resources. There is also a need to create a functional infrastructure for oncofertility services. However, even countries with established services for patients face problems. For instance, in the United States fertility preservation services are currently available to most patients who are under the age of 45 [32] but some still have restricted access to care due to their socioeconomic situation, insurance plan or geographical location [33]. Fertility centres in Canada are enthusiastic about working together with other healthcare providers to offer fertility preservation services for cancer patients [48]. However, despite all required components are present in the Canadian system, their coordinated functioning remains challenging [52].

Despite existing fertility preservation methods for both men and women, patient wishes to be informed about fertility preservation options and a number of guidelines how fertility consultations should be addressed, physicians are still misled by their personal biases when it comes to discussing fertility preservation during consultations. We identified the studies from 
the UK, Japan, Saudi Arabia, Turkey, Iran and the USA reporting fertility preservation practices and factors influencing physician's decision to discuss fertility preservation with their patients (Table 3).

Only British and American physicians are reported to discuss fertility issues with their patients on most occasions $[53,54]$. However, American physicians tend to have more biases based on social, gender and racial factor than medical prognosis compared to the UK physicians [53]. In other countries fertility preservation consultations do not occur on regular basis and referrals to fertility specialists are even lower $[46,55,56]$. General tendency noted in most studies is that physicians are concerned with patient's prognosis $[49,53]$, type of cancer $[46,53]$ and reluctance to delay the start of treatment [49,57]. Lack of knowledge about fertility preservation and time constraints were also among the reasons why fertility preservation was not addressed by British, Japanese, Turkish and Iranian physicians (Table $3)$.

The same as with patient surveys, it has to be noted that physicians' surveys also vary in sample sizes and response rates; especially studies from Iran and Turkey have very low participant numbers. However, the methodology is more coherent and studies could be legitimately compared: postal or online questionnaires are used; attitudes, consultation and further referral practises are studied, reasons why fertility preservation issues are not discussed are also addressed by most studies. It allows concluding that successful fertility preservation programmes are still to be developed worldwide. It will require oncology specialists to become aware of the latest achievements in fertility preservation medicine, sensitiveness to individual patients' values and goals and multidisciplinary approach. Kim and colleagues suggest to have a highly skilled team consisting of oncologists, fertility specialists, embryologists, and mental health professionals [58].

One more important aspect to be mentioned is the biases physicians possess based on patients' socioeconomic background, age, partnership status, existing children, sexual orientation, and in some cases religion. It will have to be addressed in ongoing specialist training providing physicians the skills and tools to manage their biases. For instance, oncologists in Saudi Arabia have a favourable attitude towards sperm banking for male patients but referral numbers are still low [46]. In Iran nearly half oncologists think that fertility preservation topic should be brought up by patients themselves [56]. It is interesting to note that oncologist's enthusiasm about fertility preservation options does not generally 
lead to be better physician-patient relationship [59] which brings us back to the point that survival might still be primarily concern for the majority of cancer patients.

Table 3

Physician practices and factors influencing decisions

$\begin{array}{lllll}\text { Country; } & \text { Participants; } & \text { FP consultation } & \text { Factors influencing } & \text { Reference } \\ \text { Publication year } & \text { Type of survey } & \text { practises (\%) } & \begin{array}{l}\text { decision to/not to } \\ \text { discuss FP (\%) }\end{array} & \end{array}$

UK; 2013

$\begin{array}{lll}\begin{array}{l}100 \text { oncologists; } \\ \text { online }\end{array} & \begin{array}{l}\text { 97\% usually or } \\ \text { always discuss } \\ \text { treatment effect } \\ \text { on fertility }\end{array} & \begin{array}{l}93 \% \text { patient too ill to } \\ \text { delay treatment }\end{array} \\ \begin{array}{l}67 \% \text { have } \\ \text { referred patients } \\ \text { to fertility } \\ \text { specialist }\end{array} & \begin{array}{l}72 \% \text { patient has } \\ \text { hormonally sensitive } \\ \text { tumour }\end{array} \\ & \begin{array}{l}38 \% \text { provide } \\ \text { written } \\ \text { information } \\ \text { about fertility }\end{array} & \begin{array}{l}\text { has children } \\ 32 \% \text { patient is single }\end{array} \\ & 27 \% \text { patient could not } \\ & \text { afford FP }\end{array}$

afford FP

$21 \%$ patient is

homosexual

$\mathrm{UK} ; 2012$

\begin{tabular}{|c|c|}
\hline $\begin{array}{l}306 \text { surgeons, } \\
\text { oncologists, } \\
\text { clinical nurse } \\
\text { specialists } \\
\text { working with } \\
\text { breast cancer } \\
\text { patients; online }\end{array}$ & $\begin{array}{l}\text { Average number } \\
\text { of referrals to } \\
\text { fertility unit was } \\
3 \text { patients (range } \\
0-25 \text { ) per } \\
\text { respondent in } \\
\text { the last } 12 \\
\text { months }\end{array}$ \\
\hline
\end{tabular}

$78 \%$ patients age

$37,9 \%$ final

tumour/node/metastasis

status

$37,3 \%$ concern that it delay chemotherapy

$33,5 \%$ whether patient already has children 
$24,7 \%$ whether patient has partner

$22,6 \%$ estrogen

receptor expression

$20,9 \%$ lack of

knowledge

$19,9 \%$ concern that FP would compromise the treatment success

Japan; 2013

\begin{abstract}
434 breast
oncologists;

paper surveys

sent by mail
\end{abstract}

$83 \%$ positive in

$51 \%$ high risk of

discussing FP

cancer reoccurrence

$42 \%$ refer

$45 \%$ lack of

patients to

reproductive specialists

reproductive

specialist when

$45 \%$ time constraints

patients express

concerns

Saudi Arabia;

103 medical,
radiation and
surgical
oncologists
working with
male patients;
self
administered
questionnaire

94\% felt that FP

$92 \%$ type of cancer

2010

help patients

psychologically

$87 \%$ patient's age

$42 \%$ routinely

$82 \%$ marital status

discuss FP with

patients

$84 \%$ number of

existing children

$63 \%$ positive

about discussing

FP with parents

$69 \%$ cost of sperm

of prepubertal

boys

cryopreservation

$2,9 \%$ religion

$39 \%$ never refer

patients to FP

specialist

$19,5 \%$ refer

patients to 
fertility

specialist

Turkey; $2012 \quad 25$

$35 \%$ insurance does

not cover FP

$33 \%$ patients cannot

afford to pay FP haematologists;
questionnaire

$60 \%$ did not

Not provided

inform their

patients about

FP

$76 \%$ did not feel

they have

enough

knowledge about

FP

$80 \%$ expressed

approval of

postponing

treatment for a

short period to

accommodate

FP

30 oncologists; $\quad 46 \%$ knew about $\quad 67 \%$ believed FP

questionnaire $\quad F P$ techniques

should be offered to all

patients at risk

$40 \%$ insisted

that patients

have to bring FP

topic themselves

$55 \%$ refer to

$92 \%$ patients were

[60]

hematopoietic

fertility

specialist

already infertile

$63 \%$ patients were too

ill to delay transplant

physicians;

online 
$27 \%$ time constraints

$16 \%$ no sufficient

knowledge

$15 \%$ do not have

information to give to

patients about FP

14\% patients do not

want to discuss FP

$12 \%$ there is no $\mathrm{FP}$

specialist

USA; 2010

249 oncologists

95\% discuss FP

$30 \%$ poor prognosis

working with

female patients;

$5,8 \%$ always

$22 \%$ need to initiate

online

refer to fertility

therapy in 1-2 weeks

specialist

$10 \%$ patient has a child

$33,2 \%$ usually

already

refer to fertility

specialist

$8 \%$ poor success of FP

$43,3 \%$ rarely

$7 \%$ patient too young to have children

$17,8 \%$ never

$6 \%$ limited knowledge of risks

$5 \%$ lack of availability of FP services

$4 \%$ cost is prohibitive

$2 \%$ patient is a lesbian

$1 \%$ patient is not

married

USA; 2009

613 oncologists

$46,7 \%$ always or

Not provided

working with

often referred 


$\begin{array}{ll}\text { adult patients; } & \text { patients who had } \\ \text { postal survey } & \text { questions about } \\ \text { and online } & \text { fertility to } \\ \text { survey } & \text { fertility } \\ & \text { specialist }\end{array}$

\section{Practicalities to consider in oncofertility consultation}

Fertility preservation consultation is an additional concern on top of cancer treatment but it is becoming generally agreed that addressing fertility issues in cancer care should become a standard practice (Table 1). Discussing treatment consequences on sexuality and fertility might involve more parties than just patients and physicians. Children have parents who are there to represent the best interests of the children, patients in committed relationships might want to have their partners involved in decision making, some cultures and faiths might see fit to have other family members, friends and/or religious or community leaders involved. Up to date there is not much research done on the involvement of other parties in fertility preservation decision making. Research focusing on the partners of cancer survivors and their concerns regarding fertility is suggested [40] but not accomplished to date. However partner's involvement in fertility consultation is suggested by EUSOMA guidelines [37]. Considering the above mentioned concerns, some scholars urge the need to focus on oncofertility implications on both societal and individual levels [62]. Important points to consider when creating functional oncofertility system are proposed to include the following: privacy and confidentiality; consent/assent; safety and efficacy of experimental techniques; conflict of interest regarding patient needs and personal/institutional financial incentives; age restrictions (minimum and maximum); future use of stored tissue, gametes, and embryos; creation of centralized registry of those who preserve their fertility [63]. Decision support interventions, like decision counselling or decision coaching, are tools designed to help patients to participate in specific and deliberated decision making among health-related options. They help patients to recognize the values-sensitive nature of the decision and to clarify, either implicitly or explicitly, the value they place on the benefits, harms, and scientific uncertainties [64,65].

Moreover, it is important to keep in mind that the field of fertility preservation in cancer patients, as well as that of infertility treatments, was shaped by medical and non-medical 
factors such as societal attitudes regarding infertile people, having children as means of survival and work-force or, what is more common in modern society, seeking fulfilment in life [66]. Ethical issues are important aspect of decision-making process. Therefore, we would like to suggest that ethical aspects should be included in decision support interventions. As well as financial aspects of fertility preservation procedures should not be overlooked. Insurance coverage for fertility preservation treatment is one of the most debated questions in the USA [7]. Some argue that there is little ethical justification to withhold insurance coverage for fertility preservation technologies [16] while reservations can still be expressed especially when it comes at tax payers' expense. Various experts have debated on what factors should be targeted to eliminate disparities including socioeconomic status, race, biology, access to care, lack of insurance, stage of the disease at the diagnosis [33]. United States had a 14\% decrease in mortality from cancer in a period between 1991 and 2004 but it has not benefited to all segments of the population, as a response ASCO issued a policy statement pointing out that low income, lack of insurance and restricted access to care are playing a major role in health disparities [67]. In a later report ASCO concluded that providing quality care to all patients with cancer, regardless of their racial, socioeconomic, or geographical group, is a priority [68].

Preserving fertility impose significant costs and in case of cancer patients it is not clear if cryopreserved material will ever be used for the benefit of the patient. Initial oocyte retrieval cost is advertised $\$ 6000-12000$ plus $\$ 2000-5000$ for medication (2014-01-31 at Extended Fertility Website http://www.extendfertility.com/about/faq.php), annual storage fee with Extended Fertility in Massachusetts is reported to be $\$ 440$ [69]. In Germany patients have to cover the costs of fertility preservation themselves: cryopreservation of fertile eggs costs about 3000 Euros, sperm cryopreservation about 350 Euros, storage of either about 250 Euros a year [39]. The cost of fertility treatment led to proposal of guidelines where two the most important inclusion criteria for experimental gonadal tissue cryopreservation are urged to be a high risk of future infertility and a high likelihood of long-term survival because commercialisation of medical interventions can lead to irrational investments [70]. The annual storage fee for cryopreserved materials could easily become a source of psychological pressure and financial burden rather than future opportunity [71].

Therefore we would like to suggest that more attention has to be paid to designing decisional support services for cancer patients. Informing patients (their parents or guardians) how cancer treatment could affect future fertility in age, disease and gender specific way is 
already a standard imposed by many professional guidelines (Table 1). Providing information about fertility preservation options while referring patient to the specialist when patient is interested in fertility preservation is also practice supported by many physicians (Table 3 ). However, high quality patient care does not end with referral to another specialist. Other types of support have high potential to benefit cancer patients too. We provide more details in Table 4 and suggest that a high quality cancer care should includes multiple steps in sometimes very short period of time which will require close and efficient collaboration among a wide range of specialists. Assisting patients to understand the implications of their condition to their future life and choosing fertility preservation options accordingly we consider the core part of decisional counselling services. Furthermore, we suggest focusing on patient's values based on their personal philosophy and view of life, spirituality and sometimes emotions ignited by cancer diagnosis which would shape their goals and consequentially decisions leading to practicalities such as national legislation of fertility preservation procedures and financial implications.

Table 4

Decisional support types when counselling cancer patients about fertility preservation Support type Key features

1. Understanding Disease impact on future life: medical and clinical reality -what functions will be impaired

- what are treatment side effects

- what are survival rates

- what care will be needed during treatment and after it is finished

2. Informing Established and experimental options:

about fertility preservation - local availability

options

- success rates

- risks and benefits 
- costs

- who will cover the costs: public health system, private insurance, charities, private funds

3. Identifying Personal values and goals in the light of the prognosis:

patient's

expectations

- what treatment is acceptable

- what are the tenets of patient's personal philosophy

- how much risk (survival versus fertility) patient is ready to accept

- how important is fertility, survival, quality of life

4. Legal guidance*

Local, regional, national, federal legislation on fertility preservation methods

5. Psychological Fear, anxiety, present and anticipated guilt and emotional support*

6. Spiritual Are there religious preferences? and/or religious guidance* -what FP methods are acceptable

- what FP would mean

7. Financial Planning finances during cancer treatment: counselling*

- reduced capacity to work

- lower income during the course of treatment

- personal care expenses

- cancer treatment expenses not covered by insurance

- childcare (if any) expenses 
- fertility preservation (treatment and storage) expenses

* These counselling services could be optional, depending on the need and relevance in a specific situation

\section{Conclusions}

In most cases the main cause of infertility in cancer patients is treatment, not the disease. Therefore, consultation for fertility preservation should take place before cancer treatment. The established and experimental methods to preserve fertility are now available in many centres and cancer patients demonstrate interest in fertility preservation. Nonetheless, a significant number of patients worldwide are not given information about the detrimental effects on fertility of cancer treatments and the possibilities to preserve fertility. Physicians are still misled by their personal judgmental biases on whom to offer fertility preservation consultation. Lack of time and knowledge about existing options, poor prognosis, and delay in treatment, patient's age, partnership status, existing children and socioeconomic situation are identified as the main barriers to initiate the consultation. Moreover, fertility preservation consultation is not limited to medical aspects. Patient's needs, values and priorities have to be addressed within the context of medical necessities, realistic survival forecast, socio-cultural environment and availability of resources. We suggest a framework for improving decisional support services for cancer patients who would like to consider fertility preservation options. Our proposal is based on helping patients to clarify the implications of their condition for the future life, identify the values on which their base their personal philosophy of life and address practical aspects of the preferred decision on fertility preservation procedures.

\section{Bibliography}

[1] De Angelis R, Sant M, Coleman MP, Francisci S, Baili P, Pierannunzio D, et al. Cancer survival in Europe 1999-2007 by country and age: results of EUROCARE-5-a population-based study. Lancet Oncol 2014;15(1):23-34. doi:10.1016/S14702045(13)70546-1.

[2] Gatta G, Botta L, Rossi S, Aareleid T, Bielska-Lasota M, Clavel J, et al. Childhood cancer survival in Europe 1999-2007: results of EUROCARE-5-a population-based study. Lancet Oncol 2014;15(1):35-47. doi:10.1016/S1470-2045(13)70548-5.

[3] Armenian SH, Landier W, Hudson MM, Robison LL, Bhatia S. Children's Oncology Group's 2013 blueprint for research: survivorship and outcomes. Pediatr Blood Cancer 2013;60(6):1063-8. doi:10.1002/pbc.24422. 
[4] Ward E, Desantis C, Robbins A, Kohler B, Jemal A. Childhood and adolescent cancer statistics, 2014. CA Cancer J Clin 2014;64(2):83-103. doi:10.3322/caac.21219.

[5] Coleman MP, Quaresma M, Berrino F, Lutz JM, De Angelis R, Capocaccia R. Cancer survival in five continents: a worldwide population-based study (CONCORD). Lancet Oncol 2008;9(8):730-56. doi:10.1016/S1470-2045(08)70179-7.

[6] Haggar FA, Pereira G, Preen DD, Holman CDJ, Einarsdottir K. Cancer survival and excess mortality estimates among adolescents and young adults in Western Australia, 1982-2004: a population-based study. PloS One 2013;8(2):1-8. doi:10.1371/journal.pone.0055630.

[7] Campo-Engelstein L. Consistency in insurance coverage for iatrogenic conditions resulting from cancer treatment including fertility preservation. J Clin Oncol 2010;28(8):1284-6. doi:10.1200/JCO.2009.25.6883.

[8] Meistrich ML. Male gonadal toxicity. Pediatr Blood Cancer 2009;53(2), 261-6. doi:10.1002/pbc.22004.

[9] Hartman M, Liu J, Czene K, Miao H, Chia KS, Salim A. Birth rates among female cancer survivors: a population-based cohort study in Sweden. Cancer 2013;119(10): 1892-9. doi:10.1002/cncr.27929.

[10] Kondapalli LA, Crisci A. Incorporating Insurance Education into the Fertility Preservation Process. In: Woodruff TK, Clayman ML, Waimey KE, editors . Oncofertility Communication: Sharing Information and Building Relationships across Disciplines, New York: Springer; 2014, p. 167-80. doi:10.1007/978-1-4614-8235-2.

[11] Ginsberg JP. Gonadotoxicity of Cancer Therapies in Pediatric and Reproductive-Age Males. In: Gracia C, Woodruff TK, editors. Oncofertility Medical Practice: Clinical Issues and Implementation, New York: Springer; 2012, p. 15-23. doi:10.1007/978-14419-9425-7.

[12] Levine J. Gonadotoxicity of Cancer Therapies in Pediatric and Reproductive-Age Females. In: Gracia C, Woodruff TK, editors. Oncofertility Medical Practice: Clinical Issues and Implementation, New York: Springer; 2012, p 3-14.

[13] Resetkova N, Hayashi M, Kolp LA, Christianson MS. Fertility Preservation for Prepubertal Girls: Update and Current Challenges. Curr Obstet Gynecol Rep 2013;2(4): 218-25. doi:10.1007/s13669-013-0060-9.

[14] Ogilvy-Stuart AL, Clayton PE, Shalet SM. Cranial irradiation and early puberty. J Clin Endocrinol Metab 1994;78(6):1282-6. doi:10.1210/jcem.78.6.8200926

[15] Andres MM, Wallace WHB. Practical and ethical issues for fertility preservation for children and young people with cancer. Paediatr Child Health 2010;20(3):135-142. doi:10.1016/j.paed.2009.10.004.

[16] Shah DK, Goldman E, Fisseha S. Medical, ethical, and legal considerations in fertility preservation. Int J Gynaecol Obstet 2011;115(1):11-5. doi:10.1016/j.ijgo.2011.05.011. 
[17]Brannigan RE. Fertility Preservation in Adult Male Cancer Patients. In: Woodruff TK, Snyder KA, editors. Oncofertility: Fertility Preservation for Cancer Survivors, Boston: Springer; 2007, p. 28-49. doi:10.1007/978-0-387-72293-1.

[18] Van der Kaaij MAE, van Echten-Arends J, Heutte N, Meijnders P, Abeilard-Lemoisson E, Spina M. Cryopreservation, semen use and the likelihood of fatherhood in male Hodgkin lymphoma survivors: an EORTC-GELA Lymphoma Group cohort study. Hum Reprod 2013;29(3):525-533. doi:10.1093/humrep/det430.

[19]Horne G, Atkinson AD, Pease EHE, Logue JP, Brison DR, Lieberman BA. Live birth with sperm cryopreserved for 21 years prior to cancer treatment: case report. Hum Reprod 2004;19(6):1448-9. doi:10.1093/humrep/deh249.

[20] Trost L, Brannigan R. Fertility Preservation in Males. In: Gracia C, Woodruff TK, editors. Oncofertility Medical Practice: Clinical Issues and Implementation, New York: Springer; 2012, p. 27-50. doi:10.1007/978-1-4419-9425-7.

[21]Fujita K, Tsujimura A. Fertility preservation for boys with cancer. Reprod Med Biol 2010; 9(4):179-84. doi:10.1007/s12522-010-0061-6.

[22]Loren AW, Mangu PB, Beck LN, Brennan L, Magdalinski AJ, Partridge AH, et al. Fertility preservation for patients with cancer: American Society of Clinical Oncology clinical practice guideline update. J Clin Oncol 2013;31(19):2500-10. doi:10.1200/JCO.2013.49.2678.

[23] Peccatori FA, Azim HA, Orecchia R, Hoekstra HJ, Pavlidis N, Kesic, et al. Cancer, pregnancy and fertility: ESMO Clinical Practice Guidelines for diagnosis, treatment and follow-up. Ann Oncol2013;24 Suppl 6(May):160-70. doi:10.1093/annonc/mdt199.

[24] Noyes N, Porcu E, Borini A. Over 900 oocyte cryopreservation babies born with no apparent increase in congenital anomalies. Reprod Biomed Online 2009;18(6): 769-76. doi:10.1016/S1472-6483(10)60025-9.

[25] Azim A, Costantini-Ferrando M, Oktay K. Safety of fertility preservation by ovarian stimulation with letrozole and gonadotropins in patients with breast cancer: a prospective controlled study. J Clin Oncol 2008;26(16):2630-5.

[26] Kondapalli LA. Ovarian Tissue Cryopreservation and Transplantation. In: Gracia C, Woodruff TK, editors. Oncofertility Medical Practice: Clinical Issues and Implementation, New York: Springer; 2012, p. 63-75. doi:10.1007/978-1-4419-9425-7.

[27] Jadoul P, Dolmans M-M, Donnez J. Fertility preservation in girls during childhood: is it feasible, efficient and safe and to whom should it be proposed? Hum Reprod Update 2010;16(6):617-30. doi:10.1093/humupd/dmq010.

[28] Anderson RA, McLaughlin M, Wallace WHB, Albertini DF, Telfer EE. The immature human ovary shows loss of abnormal follicles and increasing follicle developmental 
competence through childhood and adolescence. Hum Reprod 2014;29(1):97-106. doi:10.1093/humrep/det388.

[29]Dolmans M-M, Jadoul P, Gilliaux S., Amorim CA, Luyckx V, Squifflet J, et al. A review of 15 years of ovarian tissue bank activities. J Assist Reprod Genet 2013;30(3):305-14. doi:10.1007/s10815-013-9952-x.

[30] Silber SJ. Ovary cryopreservation and transplantation for fertility preservation. Mol Hum Reprod 2012;18(2):59-67. doi:10.1093/molehr/gar082.

[31]Donnez J, Jadoul P, Squifflet J, Van Langendonckt A, Donnez O, Van Eyck A-S, et al. Ovarian tissue cryopreservation and transplantation in cancer patients. Best Pract Res Clin Obstet Gynaecol 2010;24(1):87-100. doi:10.1016/j.bpobgyn.2009.09.003.

[32] Llarena NC, Jeruss JS. Fertility Communication and High-Risk Patients. In: Woodruff TK, Clayman ML, Waimey KE, editors . Oncofertility Communication: Sharing Information and Building Relationships across Disciplines, New York: Springer; 2014, p. 61-72. doi:10.1007/978-1-4614-8235-2..

[33] Dunn BK, Agurs-Collins T, Browne D, Lubet R, Johnson KA. Health disparities in breast cancer: biology meets socioeconomic status. Breast Cancer Res Treat 2010;121(2):281-92. doi:10.1007/s10549-010-0827-X.

[34]Lewis PE, Sheng M, Rhodes MM, Jackson KE, Schover LR. Psychosocial concerns of young African American breast cancer survivors. J Psychosoc Oncol 2012;30(2):16884. doi:10.1080/07347332.2011.651259.

[35] American Society for Reproductive Medicine. Fertility preservation and reproduction in patients facing gonadotoxic therapies: a committee opinion. Fertil Steril 2013;100(5): 1224-31. doi:10.1016/j.fertnstert.2013.08.041.

[36]Coccia PF, Pappo AS, Altman J, Bhatia S, Borinstein SC, Flynn J, et al. Adolescent and young adult oncology, version 2.2014. J Natl Compr Canc Netw 2014;12(1):21-32.

[37] Cardoso F, Loibl S, Pagani O, Graziottin A, Panizza P, Martincich L, et al. The European Society of Breast Cancer Specialists recommendations for the management of young women with breast cancer. Eur J Cancer 2012;48(18):3355-77. doi:10.1016/j.ejca.2012.10.004.

[38] Corney RH, Swinglehurst AJ. Young childless women with breast cancer in the UK: a qualitative study of their fertility-related experiences, options, and the information given by health professionals. Psychooncology 2014;23(1):20-6. doi:10.1002/pon.3365.

[39] Geue K, Richter D, Schmidt R, Sender A, Siedentopf F, Brähler E, et al.The Desire for Children and Fertility Issues Among Young German Cancer Survivors. J Adolesc 2014;54(5):527-35. doi: 10.1016/j.jadohealth. 
[40]Penrose R, Beatty L, Mattiske J, Koczwara B. Fertility and cancer - a qualitative study of Australian cancer survivors. Support Care Cancer 2012;20:1259-65.

doi:10.1007/s00520-011-1212-y.

[41] Yee S, Abrol K, McDonald M, Tonelli M, Liu KE. Addressing oncofertility needs: views of female cancer patients in fertility preservation. J Psychosoc Oncol 2012;30(3): 331-46. doi:10.1080/07347332.2012.664257.

[42]Niemasik EE, Letourneau J, Dohan D, Katz A, Melisko M, Rugo H, et al. Patient perceptions of reproductive health counseling at the time of cancer diagnosis: a qualitative study of female California cancer survivors. J Cancer Surviv Res Pract 2012;6(3):324-32. doi:10.1007/s11764-012-0227-9.

[43]Hauenstein E, Seidl S, Schneider KTM, Fischer T. Stillbirth in week 19 of pregnancy followed by maternal death as a consequence of refused chemotherapy for nonhodgkin's lymphoma--significance of adjuvant chemotherapy in women of reproductive age. Onkologie 2010;33(12):692-4. doi:10.1159/000322213.

[44]Letourneau JM, Ebbel EE, Katz PP, Katz A, Ai WZ, Chien AJ, et al. Pretreatment fertility counseling and fertility preservation improve quality of life in reproductive age women with cancer. Cancer 2012;118(6):1710-7. doi:10.1002/cncr.26459.

[45] Armuand GM, Rodriguez-Wallberg KA, Wettergren L, Ahlgren J., Enblad G, Höglund $\mathrm{M}$, et al. Sex differences in fertility-related information received by young adult cancer survivors. J Clin Oncol 2012;30(17):2147-53. doi:10.1200/JCO.2011.40.6470.

[46] Rabah DM, Wahdan IH, Merdawy A, Abourafe B, Arafa MA. Oncologists' knowledge and practice towards sperm cryopreservation in Arabic communities. J Cancer Surviv Res Pract 2010;4(3):279-83. doi:10.1007/s11764-010-0140-z.

[47] Gonçalves V, Sehovic I, Quinn G. Childbearing attitudes and decisions of young breast cancer survivors: a systematic review. Hum Reprod Update 2013;20(2):279-292. doi:10.1093/humupd/dmt039.

[48] Yee S, Buckett W, Campbell S, Yanofsky R, Barr RD. A national study of the provision of oncofertility services to female patients in Canada. J Obstet Gynaecol Canada 2012;34(9):894-58.

[49]King JW, Davies MC, Roche N, Abraham JM, Jones AL. Fertility preservation in women undergoing treatment for breast cancer in the UK: a questionnaire study. Oncologist 2012;17(7):910-6. doi:10.1634/theoncologist.2012-0064

[50] Ruddy KJ, Gelber SI, Tamimi RM, Ginsburg ES, Schapira L, Come S, et al. Prospective study of fertility concerns and preservation strategies in young women with breast cancer. J Clin Oncol 2014;32(11):1151-6. doi:10.1200/JCO.2013.52.8877. 
[51]Hill KA, Nadler T, Mandel R, Burlein-Hall S, Librach C, Glass K, et al. Experience of young women diagnosed with breast cancer who undergo fertility preservation consultation. Clin Breast Cancer 2012;12(2):127-32. doi:10.1016/j.clbc.2012.01.002.

[52] Ronn R, Holzer HEG. Oncofertility in Canada: an overview of Canadian practice and suggested action plan. Curr Oncol 2013;20(5):465-74. doi:10.3747/co.20.1361.

[53] Adams E, Hill E, Watson E. Fertility preservation in cancer survivors: a national survey of oncologists' current knowledge, practice and attitudes. Br J Cancer 2013;108(8): 1602-15. doi:10.1038/bjc.2013.139.

[54] Forman EJ, Anders CK, Behera MA. A nationwide survey of oncologists regarding treatment-related infertility and fertility preservation in female cancer patients. Fert Steril 2010;94(5):1652-6. doi:10.1016/j.fertnstert.2009.10.008.

[55]Küçük M, Yavaşoğlu I, Bolaman AZ, Kadıköylü G. Knowledge, attitudes, and practices of hematologists regarding fertility preservation in Turkey. Turkish J Haematol 2013;30(3):269-74. doi:10.4274/Tjh.2012.0015.

[56] Ghorbani B, Madahi P, Shirazi E, Ardekani HS, Kamali K. Iranian Oncologists' Attitude towards Fertility Preservation in a Sample Group. J Reprod Infertil 2011;12(1): 33-6.

[57] Shimizu C, Bando H, Kato T, Mizota Y, Yamamoto S, Fujiwara Y. Physicians' knowledge, attitude, and behavior regarding fertility issues for young breast cancer patients: a national survey for breast care specialists. Breast Cancer 2013;20(3):230-40. doi:10.1007/s12282-011-0328-8.

[58] Kim J, Kim KH, Mersereau JE. Building a successful fertility preservation program at a major cancer center. J Gynecol Oncol 2014;25(2):148-154. doi:10.3802/jgo.2014.25.2.148.

[59] Snyder KA, Pearse WB. How Do Cancer Patients Learn About Fertility Preservation? Five Trajectories of Experience. In: Woodruff TK, Clayman ML, Waimey KE, editors. Oncofertility Communication: Sharing Information and Building Relationships across Disciplines. New York: Springer; 2014, p. 3-17. doi:10.1007/978-1-4614-8235-2.

[60]Loren AW, Brazauskas R, Chow EJ, Gilleece M, Halter J, Jacobsohn DA et al. Physician perceptions and practice patterns regarding fertility preservation in hematopoietic cell transplant recipients. Bone Marrow Transplant 2013;48(8):1091-7. doi:10.1038/bmt.2013.13.

[61]Quinn GP., Vadaparampil ST, Lee J-H, Jacobsen PB, Bepler G, Lancaster J, et al. Physician referral for fertility preservation in oncology patients: a national study of practice behaviors. J Clin Oncol 2009;27(35):5952-7. doi:10.1200/JCO.2009.23.0250. 
[62]Rodriguez S, Campo-Engelstein L, Emanuel L. Fertile future? Potential social implications of oncofertility. J Clin Oncol 2013;31(6):665-7.

doi:10.1200/JCO.2012.44.0990.

[63]Rodriguez SB, Campo-Engelstein L, Clayman ML, Knapp C, Quinn G, Zoloth L, et al. Pathways toward the future: points to consider for oncofertility oversight. J Cancer Surviv 2013;7(1):140-5. doi:10.1007/s11764-012-0255-5.

[64] Stacey D, Kryworuchko J, Bennett C, Murray MA, Mullan S, Légaré F. Decision coaching to prepare patients for making health decisions: a systematic review of decision coaching in trials of patient decision AIDS. Med Decis Mak an Int J Soc Med Decis Mak 2012;32(3):22-33. doi:10.1177/0272989X12443311

[65] Stacey D, Légaré F, Col N, Bennett C, Barry M, Eden K, et al. Decision aids for people facing health treatment or screening decisions. Cochrane Database Syst Rev. 2014;(1). doi:10.1002/14651858.C D001431.pub4.

[66]Rodriguez S. Placing the History of Oncofertility. In: Woodruff TK, Zoloth L, CampoEngelstein L, Rodriguez S, editors. Oncofertility: Ethical, Legal, Social, and Medical Perspectives. Boston: Springer; 2010, p. 103-10. doi:10.1007/978-1-4419-6518-9.

[67] Goss E, Lopez AM, Brown CL, Wollins DS, Brawley OW, Raghavan D. American society of clinical oncology policy statement: disparities in cancer care. J Clin Oncol 2009;27(17):2881-5. doi:10.1200/JCO.2008.21.1680.

[68] Moy B, Polite BN, Halpern MT et al. American Society of Clinical Oncology policy statement: opportunities in the patient protection and affordable care act to reduce cancer care disparities. J Clin Oncol 2011;29(28):3816-24.

doi:10.1200/JCO.2011.35.8903.

[69] Harwood K. Egg freezing: a breakthrough for reproductive autonomy? Bioethics 2009;23(1):39-46. doi:10.1111/j.1467-8519.2008.00680.x.

[70] Mertes H, Pennings G. Testicular tissue cryopreservation: combining access with safeguards. Am J Bioeth 2013;13(3):46-8. doi:10.1080/15265161.2012.760682.

[71] Satkoske VB, Parker LS. Preserving testicular tissue and a boy's open reproductive future. Am J Bioeth 2013;13(3):36-7. doi:10.1080/15265161.2013.760984. 